\title{
Fatigue Characteristics of Medium Carbon Steel after Heat Treatment Using Sand as Cooling Media
}

\author{
Sunardi $^{1, *, a}$, Randu ${ }^{1}$, Erny Listijorini ${ }^{1}$, Iman Saefuloh ${ }^{1}$, Rina Lusiani $^{1}$, Hamdan Akbar Notonegoro ${ }^{1}$, \\ Miftahul Jannah ${ }^{1}$ \\ ${ }^{1}$ Department of Mechanical Engineering, Universitas Sultan Ageng Tirtayasa, Jl. Jendral Sudirman KM 03 Cilegon 42435 , \\ Indonesia \\ *,a sunardi@untirta.ac.id (Corresponding Author)
}

\begin{abstract}
Stress concentrations cause many machine element failures. Failure will occur more rapidly if the machine elements obtain repeated and fluctuating loading. For this reason, the material for machine elements must have better fatigue life. There are various attempts made to increase material life and other mechanical properties. In this study, the research sample used is AISI 4140 steel. The samples obtain hardening followed by cooling and tempering. The hardening temperature is $850^{\circ} \mathrm{C}$ with a holding time of 17 minutes. The cooling media in this research are dry sand, semi-wet sand, and wet sand. Wet measurements based on volumetric ratios. Semi-wet sand with a ratio of sand and water 4: 1 , sandy sand 4: 2 . The final process is tempering treatment, with a temperature of $250^{\circ} \mathrm{C}$. The material fatigue test refers to the JIS Z 2274 Standard. From this study, the heat treatment given can reduce the fatigue life of the material, even though the hardness increases. The higher the cooling rate, the hardness of the material increases, but the fatigue life is low.
\end{abstract}

Keywords-medium carbon steel, heat treatment, sand, hardness, fatigue life

\section{Introduction}

The failure of steel structures is $80-90 \%$ due to fatigue loading [1]. This failure will be faster if the machine elements have stress concentration. Some methods can increase the material's fatigue life, such as heat treatment, shot peening, forgings, extrusion, and other mechanical treatments. One of the methods widely used to improve material capability is heat treatment. Heat treatment influences changes in the mechanical and chemical properties of steel. Heat treatment is changing metal's properties by changing the microstructure through heating and cooling rate adjustments.
Heat treatment has four basic processes: hardening, annealing, normalizing, and tempering. Changes in metal properties can occur on the body or metal surface. Flame hardening using oxy-acetylene flame at a temperature of $1000^{\circ} \mathrm{C}$ with a distance of $8-10 \mathrm{~mm}$. The cooling media used are water, polymer, and sherol. The method can increase the hardness and wear resistance of gray cast iron [2]. Medium carbon steel met an annealing temperature of $900^{\circ} \mathrm{C}$ and held for 1 hour in the furnace, followed by water and air cooling. After that, the tempering process at 300,450 , and $600^{\circ} \mathrm{C}$ for 2 hours.

Tempering temperature and holding time affect the hardness, tensile strength, and steel microstructure significantly [3-4]. The tempering temperature of 400 given to the CA-15 modified cast steel produced the highest hardness at 1 hour holding time. The higher the tempering temperature and the holding time, the lower the steel's hardness This condition also occurs in the high temper temperature process in modified 410 martensitic stainless steel, where the higher the temperature and holding time, the lower the hardness and tensile strength of the material [4].

Temperature and holding time at tempering affect the corrosion resistance of modified 410 martensite stainless steel. The corrosion rate after tempering at $700^{\circ} \mathrm{C}$ for 6 hours increased with increasing $\mathrm{NaCl}$ solution and operating temperature. The increase in temperature causes a higher corrosion rate because the oxygen diffusion rate increases [5]. 
The longer the holding time on self-tempering, the material's toughness and hardness also increase, and the corrosion rate decreases. At a tempering temperature of $200^{\circ} \mathrm{C}$, the corrosion rate reached its lowest value and hardness [6]. Carburizing pack treatment can reduce the fatigue life of the shaft material when compared to untreated materials. This situation occurs at all different surface roughness [7].

The cooling media used in the heat treatment process is very diverse, including: water [2], [8]-[15], hot water [9], [14], [16], ice water [11], [16], palm kernel [12], oil [8-9], [12]-13], [15], [17], air [8]-[11], [18], gas [17], [19], polymer [2], sherol [2], aqueous $20 \%$ polymer solution [11], salt solution [13]-[14].

The medium carbon steel undergoes annealing at $900^{\circ} \mathrm{C}$ for 1 hour, followed by cooling with water and air to give different hardness. Water-cooled samples had a higher material hardness when compared to air-cooled. However, after tempering treatment, the hardness and toughness of the material decreased [20]. SA508-3 steel is heated at $950^{\circ} \mathrm{C}$ and austenized at $880^{\circ} \mathrm{C}$ for 6 hours, followed by water, oil, and air cooling. This research shows that water and oil cooling media give the characteristics of SA-508-3 steel with a tempered martensitic structure [8].

Flame hardening at $1000^{\circ} \mathrm{C}$ can increase the hardness and wear resistance of gray cast iron [2]. Heat treatment of NST 37-2 steel could increase tensile strength, yield strength, and hardness due to plastic deformation, while the ductility and impact strength decrease due to the effect of strain hardening [10]. Hardening can increase its strength and hardness. HQ809 steel material heated at $950^{\circ} \mathrm{C}$ with a holding time of 2 hours and followed by tempering can increase its hardness. The higher the tempering temperature, the impact strength, and specific wear increase, but it does not significantly affect the corrosion rate [21].

Water, polymers, and sherol can also be used as cooling media in heat treatment. A study states that flame hardening followed by polymer cooling can produce a higher hardness than water and sherol. Nevertheless, the material's maximum wears resistance can be found in materials with water cooling media followed by polymers and sherol [2]. SA5038-3 steel heating at $950^{\circ} \mathrm{C}$ for 6 hours followed by the austenization process at $880^{\circ} \mathrm{C}$ for 6 hours, then cooled with water, oil, and air. The difference in cooling rate causes changes in the structure of the material in each sample. The microstructure by cooling water and oil will produce martensitic [8].

The Al4.5\% $\mathrm{Cu}$ alloy was heated to a temperature of $545^{\circ} \mathrm{C}$ for one hour then followed by cooling water at $0^{\circ} \mathrm{C}$ and $25^{\circ} \mathrm{C}$, and $40^{\circ} \mathrm{C}$. Cooling distilled water at $0^{\circ} \mathrm{C}$ increased $\mathrm{Al}-4.5 \%$ Cu's hardness by $23.8 \mathrm{HRC}$ [22]. Aluminum alloy $2024-\mathrm{T} 3$ heated at $490^{\circ} \mathrm{C}$ with a holding time of 2 hours shows that natural aging does not affect residual stresses' relaxation. Coolant medium 15\% polyalkylene glycol has a significant effect on residual stress relaxation but reduces the material's hardness [23].

Forged steel 30MSV6 is subjected to heat deformation at $115^{\circ}$ and $925^{\circ} \mathrm{C}$ and is followed by air cooling. Increasing the cooling rate will change the microstructure of acicular ferrite, bainite, and martensite. This treatment resulted in increased yield strength and ultimate strength, but ductility decreased significantly [24]. Water cooling media could provide the highest strength increase of $1500 \mathrm{MPa}$ due to the martensite structure's formation [9].

The characteristics of the cooling medium influence its mechanical and chemical behavior [8], [9], [18], [25]. In SA508-3 steel, to obtain low bainite, the cooling rate is $5^{0} \mathrm{C} / \mathrm{s}$. Meanwhile, ferrite and granular bainite's microstructure can be obtained at cooling rates below $3^{0} \mathrm{C} / \mathrm{s}$ [8]. This condition different from C-Mn-Cr-B steel, where the formation of bainite and martensite structures occurs at a cooling rate of $20^{\circ} \mathrm{C} / \mathrm{s}$ [9].

The low cooling rate of the A356 alloy steel forms a large plate-like eutectic, while rapid cooling can form eutectic corals or fine plates [25]. For UHSS steel with carbon and chrome content, the micro martensite structure formation is entirely at a cooling rate of $0.08^{\circ} \mathrm{C} / \mathrm{s}$. A mixed structure of bainite and martensite can form at $0.02^{\circ} \mathrm{C} / \mathrm{s}$, while granular bainite with carbide proeutectoid formation at a cooling rate of $0.01^{\circ} \mathrm{C} / \mathrm{s}$ [18].

Material's mechanical properties are affected by its elements content [26]-[28]. Sulfur addition to the 
aluminum liquid significantly increases tensile strength, hardness, wear-resistance, and friction coefficients [26]. The aluminum alloy's addition of silicon content will lower the aluminum's liquid point and increase its fluidity and tensile strength [28].

This research will be studied about sand with certain wetness as a cooling medium toward the fatigue characteristics steel material AISI 4140.

\section{Research Methodology}

\section{A. Material}

The material used is AISI 4140 steel with a carbon content of $\pm 0.40 \%$. This steel undergoes hardening treatment at a temperature of $850^{\circ} \mathrm{C}$ and then cooled using sand in dry, half wet, and wet conditions.

\section{B. Cooling Media}

The media used to cool the steel after the hardening treatment is sand with dry sand conditions, half wet sand with a volume ratio of sand and water is $4: 1$, and wet sand with a volume composition of 4:2. The volume used is liters.

\section{Sample Preparataion}

The number of samples used was 12 for the fatigue test and four samples for material hardness testing. Samples were given hardening heat treatment at $850^{\circ} \mathrm{C}$ for 17 minutes for fatigue test materials, while materials for hardness tests lasted 28 minutes. The next process is cooling down by using sand as a cooling medium - this sand with certain conditions to have different cooling rates. The samples provided by hardening are cooled to an environmental temperature.

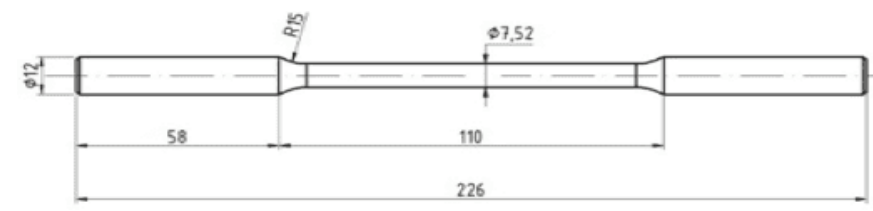

Figure 1. Specimen for fatigue testing

The final process is tempering. Tempering is performed at $250^{\circ} \mathrm{C}$ with a 30 -minute hold time for all samples. The fatigue test sample used refers to the JIS Z 2274 Standard with dimensions in the Figure 1. While

DOI : $\underline{\text { http://dx.doi.org/10.31963/intek.v8i2.2817 }}$

mp//dx.doi.org/10.31963/intek.v8i2.2817 the sample used for the hardness test has a cylindrical shape and dimensions, as shown in Figure 2.

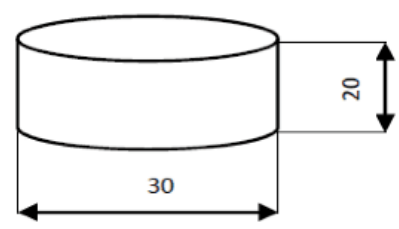

Figure 2. Specimen's dimension for hardness testing

\section{Testing Equipment}

Hardness testing was conducted at Laboratorium Metalurgi BLD PT. Krakatau Steel using Hardness Vickers Tester, with Wolpert Dia-2-RC. Sample's roughness used a surface roughness tester with brand of Mahr Perthern, Model 5SP. The fatigue testing was conducted at Balai Besar Teknologi Kekuatan Struktur BPPT, with PUPN 0223 testing machine at frequency of $50 \mathrm{~Hz}$. Olympus Metallurgical Microscope used to observe microstructure, was conducted at Metallurgical laboratory of the Faculty of Engineering, Universitas Sultan Ageng Tirtayasa.

\section{Results and Discussion}

\section{A. Chemical Composition}

The cooling media of the sample after the hardening process has no significant influence on its chemical composition. Several elements have increased chemical content, namely $\mathrm{Mn}, \mathrm{Si}, \mathrm{Cr}$, and $\mathrm{Al}$. While the decreased content is $\mathrm{C}, \mathrm{P}, \mathrm{S}, \mathrm{Cu}, \mathrm{Mo}$, and V. Details of the amount of change can be seen in Table 1.

Table 1. Chemical content of material before and after heat treatment

\begin{tabular}{|c|c|c|c|c|}
\hline \multirow{2}{*}{ Elements } & \multicolumn{4}{|c|}{ Material } \\
\cline { 2 - 5 } & $\mathrm{RM}$ & $\mathrm{DS}$ & $\mathrm{DW}$ & WS \\
\hline $\mathrm{C}$ & 0.4045 & 0.3965 & 0.3957 & 0.3941 \\
\hline $\mathrm{Mn}$ & 0.7275 & 0.7599 & 0.7648 & 0.7677 \\
\hline $\mathrm{Si}$ & 0.2792 & 0.2805 & 0.2812 & 0.2797 \\
\hline $\mathrm{P}$ & 0.0218 & 0.0221 & 0.0201 & 0.0201 \\
\hline $\mathrm{S}$ & 0.0036 & 0.0021 & 0.0014 & 0.0021 \\
\hline $\mathrm{Cr}$ & 1.0029 & 1.0049 & 0.9917 & 1.0058 \\
\hline $\mathrm{Cu}$ & 0.0391 & 0.0370 & 0.0361 & 0.0372 \\
\hline $\mathrm{Mo}$ & 0.2457 & 0.2215 & 0.2115 & 0.2157 \\
\hline $\mathrm{V}$ & 0.0083 & 0.0068 & 0.0066 & 0.0069 \\
\hline $\mathrm{Al}$ & 0.0214 & 0.0262 & 0.0230 & 0.0218 \\
\hline
\end{tabular}

The sample used in this study was medium carbon steel with a carbon content of about $0.40 \%$. After the hardening process, there was a slight decrease in carbon 
content. The change in surface hardness of the material is not caused by the carbon content but by the phase change during the hardening process.

The most significant elements that change the percentage of content are sulfur $(61.11 \%)$, vanadium (20.48\%), molybdenum (13.92\%), phosphorus (7.80\%) and manganese (5.53\%). Significant changes generally occur in samples cooled with semi-wet sand. Reduced vanadium content reduces wear-resistance and hardness. Vanadium will form hard carbides, which reduces the strength of the material. The reduced molybdenum content will weaken the tensile strength of the material. Please note that the molybdenum content in this sample is still within reasonable limits. The high $\mathrm{Al}$ content in steel can bind oxygen so that the material becomes brittle.

\section{B. Microstructure}

Before observing the microstructure, the sample was polished with sandpaper until it was smooth. After that, autosol was given to make it shiny and dipped in an etching solution (3\% HNO3 and 97\% alcohol) for 5 seconds and then dried. Microstructure photographs were carried out under a microscope at 500X magnification.

From figure 3, we can see the differences in the microstructure of each sample. The microstructure of the raw material is martensite, pearlite, and ferrite. Martensite looks like irregular needle-like fine lines, and it is hard and brittle. Also, the black pearlite structure is less visible. The soft structure of ferrite is white. Samples with dry sand cooling medium have a black pearlite structure and a white ferrite structure. The ferrite structure dominates in this sample so that the hardness of the sample is not too high. The ferrite structure is formed due to the slow cooling process. This condition is because sand is not a good conductor of heat. Different things happen to wet and half wet sand samples. The structure of martensite and pearlite dominates in these samples so that its surface's hardness has increased.

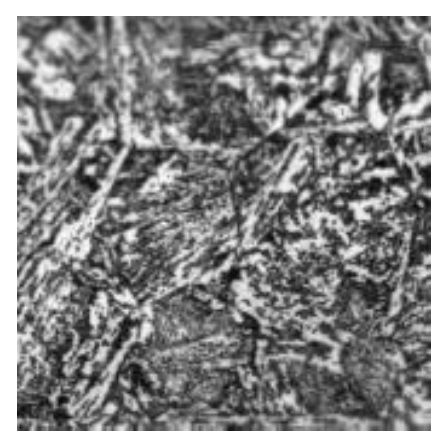

a

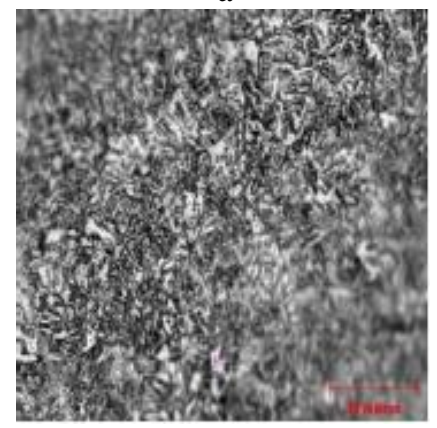

c

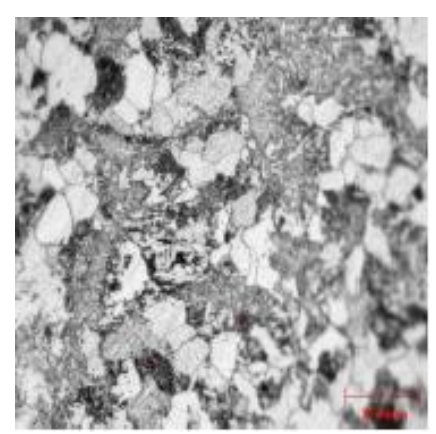

b



d
Figure 3. Microstructure of specimens (a) raw material and in sand wetness condition: (b) dry sand, (c) semi-wet sand, and (d) wet sand

\section{Hardness}

The material used in this research is AISI 4140 steel with a carbon content of about $0.40 \%$. Samples with hardening treatment change chemical element content. Surface hardness testing was carried out at five different points, and the average value was determined. The change in hardness can be seen in figure 4 . The increase in surface hardness of the material occurred significantly in materials that were cooled with water-containing sand.

The increase in hardness can reach up to $48 \%$. From this graph, it can be seen that the higher the cooling rate, the higher the hardness. Cooling using dry sand has decreased significantly. This condition is due to the relatively slow cooling speed of dry sand.

This decrease in dry sand quenching hardness is due to an increase in the amount of phosphorus. Meanwhile, phosphorus is an impurity so that it can reduce the hardness and strength of the material. The increase in hardness of steel due to cooling wet sand was caused by the increase in $\mathrm{Mn}$ and Si content. These two elements have a role to play in increasing its hardness. Besides, 
the high cooling rate also affects the microstructure. The higher the cooling rate, the less ferrite phase in the material. This condition will reduce the strength of the material.

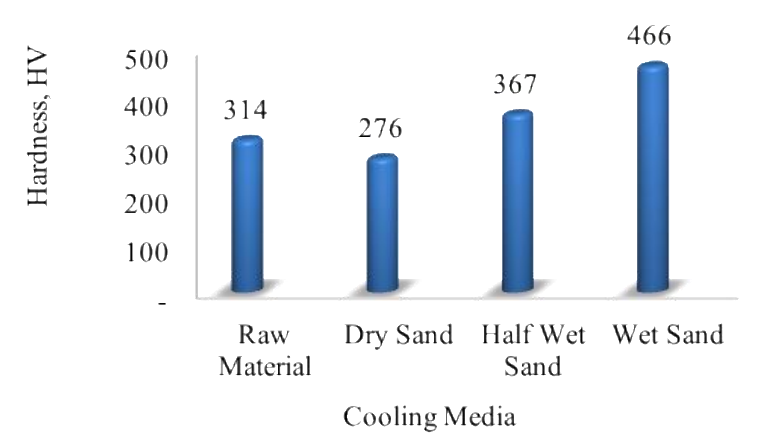

Figure 4. The effect of sand wetness on the hardness of the steel surface.

\section{Fatigue Strength}

The measurement of the material's fatigue strength is carried out using a rotary bending fatigue test machine. Stresses are taken in the 30-75\% range of the material's maximum strength, namely 345, 493, and $690 \mathrm{MPa}$. The results of material fatigue testing can be seen in Figure 5.

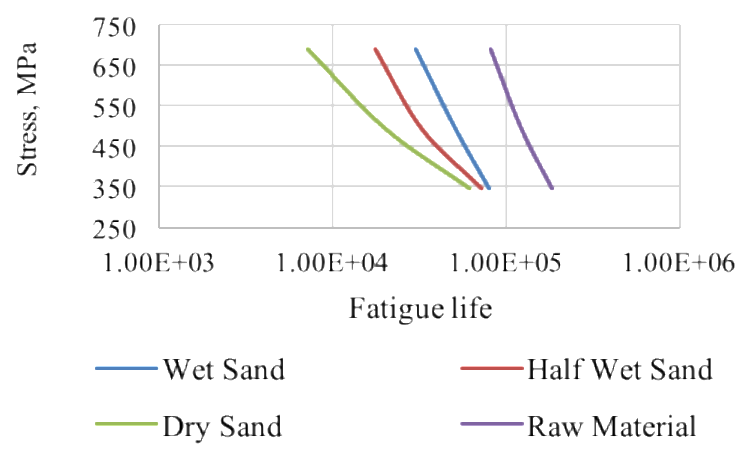

Figure 5. The effect of sand wetness on the steel's fatigue life.

In general, steel AISI 4140, which is given hardening treatment, has a significant decrease in fatigue strength. At a stress of $345 \mathrm{MPa}$, the reduction in the fatigue life of the material can reach $5-70 \%$. A unique thing happened to the material cooled with dry sand, namely the strength and fatigue strength decreased significantly. Rapid cooling decreases the fatigue life of the material, but the surface hardness increases quite significantly.
The fatigue life of the material has decreased in all cooling media conditions. Efforts to increase the fatigue strength of the material using hardening are not sufficient enough. Other heat treatment processes must accompany hardening to increase fatigue life and hardness linearly. In the samples with semi-wet and wet sand cooling media, the surface hardness increased. However, the tendency of challenging materials to be brittle and break easily.

\section{E. Fracture Surface}

The fracture surface section shows the characteristics of the material. The fracture mechanism always consists of three stages: the initial crack, the crack propagation, and the final fracture. The presence of stress concentrations acting on the surface of the material can trigger the initial cracks. The stress concentration can be in the form of keyways, changes in dimensions, and surface roughness after the manufacturing process.

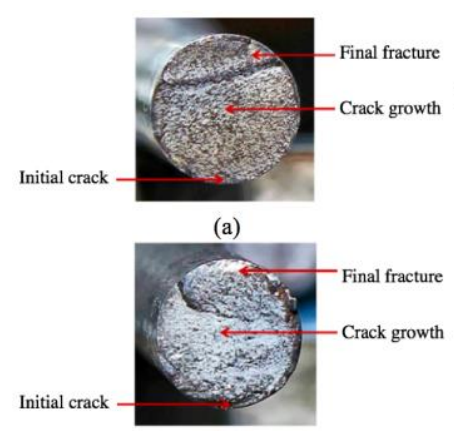

(c)

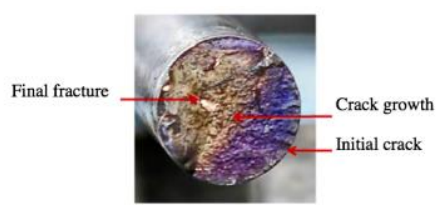

(b)

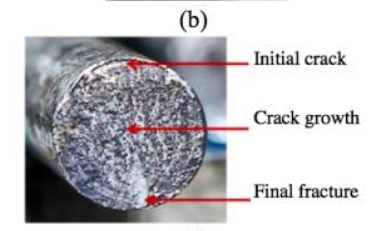

(d)
Figure 6. Fracture surfaces in sand wetness conditions (a) nontreatment, (b) dry sand, (c) semi-wet sand, and (d) wet sand.

Cracking can be caused by rough surface conditions that are not smooth. The crack spread area continues to grow during this stage as a result of continuous loading. A fracture failure occurs when a material with a crack cannot withstand the stress. This stage happens very quickly. Fatigue begins with the appearance of small, invisible cracks, which then spread during repeated loading until a brittle fracture occurs or the remaining cross-sectional area is too small to carry the load. The fracture is usually flat and bright. Usually occurs at stresses below the yield strength. These conditions are as shown in the image below. The crack propagation area is identified as on the beach mark. 


\section{Conclusion}

Heat treatment is a method to obtain the desired mechanical and chemical properties. However, the missselection of the process can reduce mechanical properties. From the previous description, it can be concluded as follows:

1. The hardening of heat-treated material reduces the fatigue life of the material.

2. The higher the cooling rate in the hardening process, the harder the resulting material's surface will be.

3. Changes in the material's mechanical properties are strongly influenced by the phase changes formed during the hardening treatment.

\section{Acknowledgement}

This research was supported by Metallurgical Laboratory - PT Krakatau Steel, Balai Besar Teknologi Kekuatan Struktur - BPPT, and Metallurgical Laboratory of the Faculty of Engineering, University of Sultan Ageng Tirtayasa. Authors would like to thank for their invaluable contribution, so that this research can be conducted very well.

\section{References}

[1] J. Volak and V. Mentl, "After 150 years of research, fatigue still causes $85 \%$ of failures," WIT Trans. Eng. Sci., Vol. 77, pp. 137-146, 2013, doi: 10.2495/MC130121.

[2] K. S. Sabarinath L., Mahesh, "Effect of Flame Hardening and Various Quenching Medium on the Mechanical and Metallurgical Properties of Grey Cast Iron Lathe Bed," Int. J. Adv. Sci. Res. Eng., Vol. 2, No. 7, pp. 1-7, 2016, [Online]. Available: http://www.ijasre.net/uploads/1/2781_pdf.pdf.

[3] A. T. Aprilliansyah, Sunardi, M. S. Anwar, and E. Mabruri, "Pengaruh Suhu dan Waktu Tempering terhadap Struktur Mikro, Kekerasan, dan Ketahanan Abrasif Baja Cor Modifikasi CA-15," J. Met. Indones., Vol. 41, No. 1, pp. 29-36, 2019, [Online].

Available: https://jurnalmetal.or.id/jmi/article/view/174/pdf.

[4] E. Mabruri, R. R. Pasaribu, M. T. Sugandi, and S. Sunardi, "Effect of High Temperature Tempering on the Mechanical Properties and Microstructure of the Modified 410 Martensitic Stainless Steel," AIP Conf. Proc., Vol. 1964, pp. 1-7, May 2018.

[5] S. Prifiharni, M. T. Sugandi, R. R. Pasaribu, S. Sunardi, and E. Mabruri, "Investigation of Corrosion Rate on the Modified 410
Martensitic stainless steel in Tempered Condition," IOP Conf. Ser. Mater. Sci. Eng., Vol. 541, pp. 1-7, 2019, doi: 10.1088/1757-899X/541/1/012001.

[6] S. Sunardi, M. Fawaid, and D. H. Nandiawan, "Pengaruh Variasi Suhu pada Proses Self Tempering dan Variasi Waktu Tahan pada Proses Tempering Terhadap Sifat Mekanis Baja AISI 4140," Vanos J. Mech. Eng. Educ., Vol. 1, No. 1, pp. 7988, 2016, [Online]. Available: http://jurnal.untirta.ac.id/index.php/vanos/article/view/835/654.

[7] Sunardi, R. Lusiani, and A. O. Fitra, "Pengaruh Pack Carburizing dan Kekasaran Permukaan Terhadap Umur Fatik Material Poros Baja S45C," J. Fundry, Vol. 3, No. 2, pp. 7-12, 2013.

[8] L. Hao, M. Sun, and D. Li, "The effect of quenching media on the microstructure and mechanical properties of SA508-3 steel," Adv. Mater. Res., Vol. 311-313, pp. 974-977, 2011, doi: 10.4028/www.scientific.net/AMR.311-313.974.

[9] S. Ojha, N. S. Mishra, and B. K. Jha, "Effect of cooling rate on the microstructure and mechanical properties of C-Mn-Cr-B Steel," Bull. Mater. Sci., Vol. 38, No. 2, pp. 531-536, 2015.

[10] D. A. Fadare, T. G. Fadara, and O. Y. Akanbi, "Effect of Heat Treatment on Mechanical Properties and Microstructure of NST 37-2 Steel," J. Miner. Mater. Charact. Eng., Vol. 10, No. 03, pp. 299-308, 2011, doi: 10.4236/jmmce.2011.103020.

[11] B. N. Sarada, P. L. S. Murthy, and S. Ramani, "Effect of Quenching Media on the Mechanical Properties of Al6061TiO2 Metal Matrix Composites," Int. J. Curr. Eng. Sci. Res., Vol. 3, No. 5, pp. 2394-0697, 2016.

[12] O. K. Abubakre, U. P. Mamaki, and R. A. Muriana, "Investigation of the Quenching Properties of Selected Media on 6061 Aluminum Alloy," J. Miner. Mater. Charact. Eng., Vol. 08, No. 04, pp. 303-315, 2009, doi: 10.4236/jmmce.2009.84027.

[13] H. I. Akbar, E. Surojo, D. Ariawan, and A. R. Prabowo, "Experimental study of quenching agents on Al6061-Al2O3 composite: Effects of quenching treatment to microstructure and hardness characteristics," Results Eng., Vol. 6, No. February, p. 100105, 2020, doi: 10.1016/j.rineng.2020.100105.

[14] S. J. Mosa, "Effect of different quenching media on mechanical properties of AISI 1018 low carbon steel," J. Mech. Eng. Res. Dev., Vol. 42, No. 3, pp. 81-83, 2019, doi: 10.26480/jmerd.03.2019.81.83.

[15] I. Equbal, P. Alam, R. Ohdar, K. A. Anand, and M. S. Alam, "Effect of Cooling Rate on the Microstructure and Mechanical Properties of Medium Carbon Steel," Int. J. Metall. Eng., Vol. 5, No. 2, pp. 21-24, 2016, doi: 10.5923/j.ijmee.20160502.01.

[16] A. D. Zeyad Kadhim, "Effect of Quenching Media on Mechanical Properties for Medium Carbon Steel," J. Eng. Res. Appl. www.ijera.com ISSN, Vol. 6, No. 85, pp. 2248-962226, 2016.

[17] K. Dybowski, J. Sawicki, P. Kula, B. Januszewicz, R. Atraszkiewicz, and S. Lipa, "The effect of the quenching method on the deformations size of gear wheels after vacuum carburizing," Arch. Metall. Mater., Vol. 61, No. 2B, pp. 10571062, 2016, doi: 10.1515/amm-2016-0178.

[18] M. Ali, D. Porter, J. Kömi, M. Eissa, H. El Faramawy, and T. Mattar, "Effect of cooling rate and composition on microstructure and mechanical properties of ultrahigh-strength steels," J. Iron Steel Res. Int., Vol. 26, No. 12, pp. 1350-1365, 
2019, doi: 10.1007/s42243-019-00276-0.

[19] E. Wołowiec-Korecka, P. Zgórniak, A. Brewka, and K. Krupanek, "Influence of quenching temperature of the individual quenching method on the geometrical dimensions of the elements," IOP Conf. Ser. Mater. Sci. Eng., Vol. 743, No. 1, 2020, doi: 10.1088/1757-899X/743/1/012048.

[20] N. M. Ismail, N. A. A. Khatif, M. A. K. A. Kecik, and M. A. H. Shaharudin, "The Effect of Heat Treatment on the Hardness and Impact Properties of Medium Carbon Steel," IOP Conf. Ser. Mater. Sci. Eng., Vol. 114, No. 012108, pp. 1-4, 2016, doi: 10.1088/1757-899X/114/1/012108.

[21] V. Malau and W. I. Fauzi, "Effects of Heat Treatments on Mechanical Properties, Specific Wear and Corrosion Rate of HQ 809 Steel for Machinery Components Application," Proc. 2018 4th Int. Conf. Sci. Technol. ICST 2018, Vol. 1, No. August 2018, pp. 1-6, 2018, doi: 10.1109/ICSTC.2018.8528600.

[22] I. Iloabachie, "Effect of Water Quenching Temperatures on the Hardness of Al-4.5\%Cu," J. Eng. Technol., vol. 7, no. 3, pp. 122-130, 2018.

[23] M. Araghchi, H. Mansouri, and R. Vafaei, "The Effects of Quenching Media and Aging on Residual Stress and Mechanical Properties of 2024 Aluminum Alloy," in Proceedings of Iran International Aluminum Conference (IIAC2016), pp. 1-3, May 2016,.
[24] D. Rasouli, S. Khameneh Asl, A. Akbarzadeh, and G. H. Daneshi, "Effect of cooling rate on the microstructure and mechanical properties of microalloyed forging steel," J. Mater. Process. Technol., Vol. 206, No. 1-3, pp. 92-98, 2008, doi: 10.1016/j.jmatprotec.2007.12.006.

[25] C. L. Yang, Y. B. Li, B. Dang, H. Bin Lü, and F. Liu, "Effects of cooling rate on solution heat treatment of as-cast A356 alloy," Trans. Nonferrous Met. Soc. China (English Ed., Vol. 25, No. 10, pp. 3189-3196, 2015, doi: 10.1016/S10036326(15)63952-8.

[26] B. Mathai, C. Mathew, P. K, and C. K. Varghese, "Effect of silicon on microstructure and mechanical properties of $\mathrm{Cu}-\mathrm{Fe}$ alloys," Int. J. Eng. Trends Technol., Vol. 29, No. 6, pp. 299303, 2015, doi: 10.1016/j.jallcom.2016.12.352.

[27] E. Mohseni, M. M. Ranjbar, M. A. Yazdi, S. S. Hosseiny, and E. Roshandel, "The effects of silicon dioxide, iron(III) oxide and copper oxide nanomaterials on the properties of selfcompacting mortar containing fly ash," Mag. Concr. Res., Vol. 67, No. 20, pp. 1112-1124, 2015, doi: 10.1680/macr.15.00051.

[28] V. Kumar, H. Mehdi, and A. Kumar, "Effect of silicon content on the mechanical properties of aluminum alloy," Int. Res. J. Eng. Technol., Vol. 2, No. 4, pp. 1326-1330, 2015, doi: 10.1088/1757-899X/71/1/012057. 